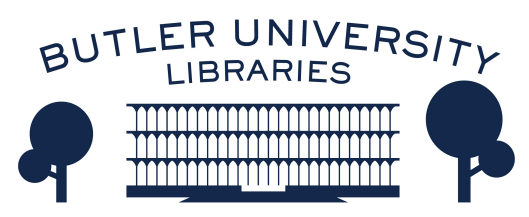

Journal of Hindu-Christian Studies

Volume 10

Article 14

January 1997

\title{
Book Review: "Seeing Through Texts: Doing Theology Among the Srivaisnavas of South India"
}

Vasudha Narayanan

Follow this and additional works at: https://digitalcommons.butler.edu/jhcs

Part of the Religion Commons

\section{Recommended Citation}

Narayanan, Vasudha (1997) "Book Review: "Seeing Through Texts: Doing Theology Among the Srivaisnavas of South India"," Journal of Hindu-Christian Studies: Vol. 10, Article 14.

Available at: https://doi.org/10.7825/2164-6279.1160

The Journal of Hindu-Christian Studies is a publication of the Society for Hindu-Christian Studies. The digital version is made available by Digital Commons @ Butler University. For questions about the Journal or the Society, please contact cbauman@butler.edu. For more information about Digital Commons @ Butler University, please contact digitalscholarship@butler.edu. 


\title{
BOOK REVIEWS
}

\author{
Seeing Through Texts: Doing Theology Among the Srivaisnavas \\ of South India. Francis X. Clooney. Albany, NY: State University of New \\ York Press, 1996.
}

CLOONEY'S BOOK IS an "endeavor of thinking and reading religiously across boundaries, an endeavor which may, in time, form a community wherein narratives can be persuasively told and systems convincingly put forward" (p.304). This is an account of the author's passionate commitment to learning and understanding the different levels of meaning in the songs of the Tiruvaymoli, a ninth-century Tamil poem.

The Tiruvaymoli of Satakopan (more popularly known as Nammalvar) has been considered to be the Tamil Veda by the Srivaisnava community of South India. It has been learnt by heart, set to music, and commented upon both verbally and dramatically by the community. Clooney's book deals with his surrender to the poem, and his commitment to his own Roman Catholic tradition. It is a book about crossing boundaries in reading texts and what may happen if one reads them with the devotion and dedication that they demand.

Clooney starts with several questions and ends the book with even more profound ones that we can explore. Can a new reader meaningfully engage with the worldview inscribed in the song (p.8)? Can readers outside the Srivaisnava tradition really understand what it would mean to worship the lord who "lay upon the waves of the sea...? Or are the intellectual, cultural, religious distances from the song to the modern reader so great as to bar any such engaged, affective encounter?" (p.8). After reading Clooney's careful exposition of the Tiruvaymoli (chapter 2) and the Srivaisnava acaryas' commentarial tradition on the poem (chapters 3 and 4), I would emphatically say that yes, an engaged reader who has, like
Clooney, learned the poem with the Srivaisnavas, can really get into the spirit of the Tiruvaymoli and become an "insider", in many meaningful contexts.

Seeing through texts has five chapters. In the first chapter we meet the texts, (the poem, the commentaries, the hagiographical literature), the Srivaisnava tradition, and the author of this book. We hear about his religious commitment (Professor Clooney is a Jesuit priest) and clearly sense his religious commitment for the Tiruvaymoli. The next three chapters take us directly to the poem and the commentarial tradition, and if like Clooney, we read the verses with sensitivity, in mastering the poem, we allow ourselves to be mastered by it. Clooney recognizes that confining oneself to the textual tradition is itself a kind of "fiction, one which stands at odds with legitimate concerns about context, history, distance, etc." (p.12). However, the other contextual traditions are just beginning to be explored and he believes we can go quite far just by "learning to think, imagine, and desire within the world bounded by the songs of the Tiruvaymoli" (p.12). Clooney postpones generalizations and dwells instead on details, lingering with care on the structure and the content of the poem, relishing the grace and magnificence of the poem.

While the whole book holds one's attention, the final chapter is of particular significance in our understanding of the theological challenges, opportunities, and perils that exist in an enterprise like this. In the first part of this chapter, Clooney takes us in "fast-forward" through several texts from the Christian tradition, and one Hindu tradition (the Mīmāmsā), composing a swift collage of passages. He discusses the Song 
of Songs, the Gospel according to John, Bonaventure's Journey of the Mind to God, the Spiritual exercises of St Ignatius Loyola, and Hans von Balthasar's Prayer, and invites the readers to enter into a project of reading back and forth between powerful texts across religious boundaries to gauge the possibilities and limits of personal commitments. For Clooney, the discourse of Bonaventure does not obliterate the discourse of the Srivaiṣnava ācārya Nampillai; adherence to the one does not preclude openness to the other (p.301). He clearly says that by reading these texts with passion and intelligence, "the way one thinks about religious things is going to be transformed... The Bible, Bonaventure, Ignatius: for a Christian who has studied the Srivaisnava tradition, these are still there, still central, but they do not mean now what they did before" (p.304). When one studies texts like the Tiruvaymoli, one will probably be changed forever by it, but the gifts of such an enterprise can be enriching:

When...one allows one's eye to play across a series of juxtaposed Christian and Srivaisnava texts, all kinds of combinations become possible; if they are not immediately subjected to a rule of faith, the one text will be allowed to linger on the periphery of a credal commitment to the other. The reader will not forget Tiruvaymoli when reading the Bible, even if, as a Christian, one is totally committed to the Gospel. Or vice versa.

This kind of openness makes possible a wider and broader range of shifting positions, even for those who remain very much committed to their own traditions, if their commitments are strong enough that openness becomes interesting, and spiritually worthwhile (p.301). Clooney does not discuss what happens when one's commitment to one's tradition is not strong enough or when the transformation leads to the rejection of one's original commitment. While the author introduces his scholarly and religious affiliations in the opening chapter, the last chapter does not disclose much by way of the changes that are wrought in his life as a result of his commitment to the Tiruvaymoli. Rather, we are led through a thoughtful and rich series of possibilities that could occur with these boundary crossings.

Seeing through texts focuses on boundary crossings which lead one directly to the heart of another tradition. While this study focuses on texts, I was reminded of other boundary crossings which occur from the Hindu side by way of shared ritual. Many Hindus in South India make pilgrimages to the shrine of St Alphonsa or frequent the dargah (shrine where a Muslim saint is buried) of Shahul Hamid in Nagore. It would be a wonderful study if these boundary crossings share similarities with those that Clooney speaks about with such ardour and erudition.

This book is a very important contribution to the fields of Srivaisnavism, theology, and religious studies. It is a remarkable account of scholarship and passion, a "must read" book for all of us who dare to open and surrender ourselves to a text or ritual of another tradition, and appropriate it for ourselves.

Vasudha Narayanan

University of Florida

\section{Jesus in Neo-Vedānta, A Meeting of Hinduism and Christianity.} K. P. Aleaz. Delhi: Kant Publications, 1995, xiv +242pp.

AS THE TITLE indicates, the focus of this volume is on the treatment of Jesus in Neo-
Vedānta. The author confines Neo-Vedānta to Swami Vivekananda, Swami Akhilananda, 